\title{
Sosialisasi Manfaat dan Pembuatan Hand Sanitizer Daun Sirih Sebagai Upaya Pencegahan Penularan Covid-19 di Desa Tehoru Kabupaten Maluku Tengah
}

\author{
La Rakhmat Wabula*1, Maryam Lihi'2, Mohammad Dahlan Sely ${ }^{3}$ \\ 1,3Program Studi Ilmu Keperawatan, STIKes Maluku Husada \\ ${ }^{2}$ Program Studi Kesehatan Masyarakat, STIKes Maluku Husada \\ *e-mail: la.rakhmat.wabula.stikesmh@gmail.com ${ }^{1}$, lihimaryam@gmail.com ${ }^{2}$, dahlansely380@gmail.com ${ }^{3}$
}

\begin{abstract}
Abstrak
Virus Covid-19 pertama kali muncul di tahun 2019. Organisasi Kesehatan Dunia (WHO) telah menetapkan virus corona sebagai pandemik. Hal ini membuat pemerintah dan masyarakat dunia makin waspada dengan penyebaran virus corona. Meski penting untuk mencari informasi terpercaya, kita juga perlu mengetahui langkah-langkah untuk membentengi diri dari stres dan panik berlebih di tengah wabah corona. Pemerintah menghimbau setiap masyarakat melakukan isolasi mandiri dan mengurangi aktivitas keluar rumah. Selain itu pemerintah juga menghimbau menerapkan pola hidup bersih untuk mencegah penularan Covid-19. Salah satunya adalah tetap menjaga tangan agar tetap bersih. Sulitnya mendapatkan hand sanitizer sekarang ini membuat masyarakat khawatir bila harus beraktifitas di luar rumah. Fenomena tersebut juga terjadi pada masyarakat Desa Tehoru Kabupaten Maluku Tengah. Sesuai dengan fenomena tersebut, maka Tim Pengabdian Masyarakat melakukan kegiatan pengabdian masyarakat berupa sosialisasi penggunaan dan pembuatan hand sanitizer berbahan dasar daun sirih di Desa Tehoru. Metode yang digunakan adalah observasi dan sosialisasi tentang penggunaan dan pembuatan hand sanitizer serta praktek langsung dengan masyarakat desa. Kegiatan ini diakhiri dengan evaluasi dan pembagian hand sanitizer untuk mencegah penyebaran Covid-19. Sosialisasi ini memiliki dampak positif terhadap masyarakat Desa Tehoru dan dari segi ekonomi dapat menurunkan biaya pengeluaran untuk pembelian produk hand sanitizer.
\end{abstract}

Kata kunci: Covid-19, hand sanitizer, daun sirih, sosialisasi

\begin{abstract}
The Covid-19 virus first appeared in 2019. The World Health Organization (WHO) has designated the coronavirus as a pandemic. This makes the government and the world community more aware of the spread of the coronavirus. Although it is important to seek reliable information, we also need to know the steps to fortify ourselves from excessive stress and panic during the corona outbreak. The government urges everyone to self-isolate and reduce activities outside the home. In addition, the government also appealed to implement a clean lifestyle to prevent the transmission of Covid-19. One of them is to keep your hands clean. The difficulty of getting hand sanitizer nowadays makes people worry when they have to do activities outside the home. This phenomenon also occurs in the community of Tehoru Village, Central Maluku Regency. Following this phenomenon, the Community Service Team carried out community service activities in the form of socializing the use and manufacture of hand sanitizers made from betel leaf in Tehoru Village. The method used is observation and socialization about the use and manufacture of hand sanitizers as well as direct practice with village communities. This activity ended with an evaluation and distribution of hand sanitizers to prevent the spread of Covid-19. This socialization has a positive impact on the people of Tehoru Village and from an economic point of view, it can reduce expenditure costs for purchasing hand sanitizer products.
\end{abstract}

Keywords: Covid-19, hand sanitizer, betel leaf, socialization

\section{PENDAHULUAN}

Coronavirus disease (Covid-19) merupakan jenis penyakit yang disebabkan oleh Coronavirus jenis baru yaitu SARS-CoV-2. Keberadaan Covid-19 berawal dari sekelompok kasus pneumonia virus yang terjadi di Wuhan, Provinsi Hubei-Cina, sejak Desember 2019 [1]. Berdasarkan data kasus yang ditemukan, Covid-19 tidak memberikan dampak yang begitu besar dengan angka kematian kecil. Dimana hingga tanggal 19 Januari 2020 hanya terjadi 2 kematian dari 198 kasus yang dilaporkan di Wuhan. Data ini menjadi acuan WHO dan pemerintah 
Indonesia secara khusus dalam menetapkan kebijakan pencegahan penularan Covid-19 [2]. Akan tetapi, penularan Covid-19 yang terjadi begitu cepat di Indonesia, khususnya pada bulan maret dengan angka kematian 4 orang dari 69 kasus menyebabkan permasalahan baru bagi pemerintah dan masyarakat [3].

Permasalahan di atas mendapat respon yang beragam dari masyarakat terkait upaya pencegahan penularan Covid-19. Usaha pencegahan yang dilakukan antara lain menghindari kontak fisik seperti jabat tangan dan memperbanyak mencuci tangan dikarenakan tangan menjadi sarana percepatan penularan mikroorganisme seperti mikroba dan virus [3]. Selain sabun, hand sanitizer menjadi pilihan lain yang penggunaannya dilaporkan meningkat secara signifikan. Hand sanitizer merupakan antiseptik pembersih tangan yang digunakan sebagai alternatif pengganti sabun [4]. Beberapa keunggulan hand sanitizer antara lain penggunaan yang simpel, mudah disimpan, dan efektif membunuh mikroorganisme di tangan dalam waktu relatif cepat [5].

Penggunaan hand sanitizer yang meningkat memberi dampak terhadap ketersediaan dan harga penjualan di pasaran. Dimana, ketersedian hand sanitizer yang terbatas di pasaran, menjadikan harga penjualan juga meningkat [6]. Fenomena tersebut juga terjadi pada masyarakat Desa Tehoru Kabupaten Maluku Tengah. Selain itu juga fenomena yang terjadi, yaitu masyarakat melakukan cuci tangan hanya menggunakan sabun. Hal ini mendorong masyarakat melakukan inovasi dalam menyediakan hand sanitizer, diantaranya adalah pembuatan hand sanitizer berbahan alam seperti daun sirih [7]. Pemilihan daun sirih didasarkan pada beberapa pertimbangan yaitu bahan baku yang melimpah di masyarakat, harga produksi murah, dan kandungan senyawa bioaktif dalam daun sirih efektif menghambat pertumbuhan atau membunuh mikroorganisme [8].

Beberapa hasil penelitian yang telah dilaporkan yaitu manfaat ekstrak daun sirih sebagai hand sanitizer untuk menurunkan angka kuman tangan [9], formulasi infusan daun sirih merah (Piper crocatum) sebagai gel antiseptik tangan [10], formulasi dan aktivitas antibakteri gel hand sanitizer ekstrak air daun sirih merah [11], formulasi minyak atsiri daun sirih hijau [12] dalam sediaan gel pencuci tangan [13], studi efektivitas sediaan gel antiseptik tangan ekstrak daun sirih (Piper betle Linn.) [7].

Dalam kegiatan pengabdian ini, kami melakukan sosialisasi manfaat dan pembuatan hand sanitizer yang dibuat dari ekstrak daun sirih sebagai upaya pencegahan penularan Covid19 pada Masyarakat Desa Tehoru Kabupaten Maluku Tengah. Metode yang digunakan adalah observasi dan sosialisasi tentang penggunaan dan pembuatan hand sanitizer serta praktek langsung dengan masyarakat. Edukasi dan sosialisasi kepada masyarakat di lakukan dengan metode tatap muka untuk berinteraksi secara langsung dengan memperhatikan protokol kesehatan.

\section{METODE}

Metode yang dilakukan, yaitu melalui sosialisasi kepada masyarakat Desa Tehoru Kabupaten Maluku Tengah terkait manfaat dan pembuatan hand sanitizer yang dibuat dari ekstrak daun sirih dengan beberapa cara berikut:

a. Metode observasi lapangan, dilakukan untuk memetakan tempat dan lokasi sosialiasi kepada masyarakat khususnya di Desa Tehoru Kabupaten Maluku Tengah.

b. Sosialisasi manfaat dan pembuatan hand sanitizer yang dibuat dari ekstrak daun sirih sebagai upaya pencegahan penularan Covid-19, dilakukan di kediaman masyarakat.

Berikut beberapa tahapan sosialisasi yang dilakukan oleh tim, sebagai berikut:

a. Tahap I (Observasi Lapangan)

Tim pengabdian melakukan kegiatan observasi lapangan yaitu di Desa Tehoru Kabupaten Maluku Tengah untuk lokasi sosialisasi. 
b. Tahap II (Kegiatan Perizinan)

Tim Pengabdian meminta izin kepada Kepala Desa Tehoru Kabupaten Maluku Tengah terkait kegiatan sosialiasi yang akan dilaksanakan. Sosialisasi ini bertujuan untuk meningkatkan pemahaman yang signifikan terutama pada masyarakat Desa Tehoru Kabupaten Maluku Tengah tentang manfaat dan pembuatan hand sanitizer yang dibuat dari ekstrak daun sirih sebagai upaya pencegahan penularan Covid-19.

c. Tahap III (Kegiatan Sosialisasi)

Sosialisasi manfaat dan pembuatan hand sanitizer yang dibuat dari ekstrak daun sirih sebagai upaya pencegahan penularan Covid-19 dilakukan pada hari Senin, 15 Maret 2021. Sosialisasi yang dilaksanakan oleh tim dilakukan di Kediaman masyarakat. Adapaun tahapan pembuatan hand sanitizer daun sirih:

1) Daun sirih (piper betle) dibilas dengan air hingga bersih

2) Dikeringkan selama beberapa menit

3) Setelah daun sirih bersih, dipotong-potong hingga ukuran kecil

4) Ditimbang sebanyak 50 gr

5) Direndam dalam $100 \mathrm{ml}$ air yang telah didihkan $\left(100^{\circ} \mathrm{C}\right)$ selama 30 menit

6) Diuapkan (dikukus) dalam panci dengan api kecil selama 30 menit

7) Didinginkan dan disaring

8) Setelah itu, ditambahkan $8 \mathrm{ml}$ jeruk nipis

9) Diaduk hingga homogen

10) Dituang dalam botol spray berukuran $100 \mathrm{ml}$

\section{HASIL DAN PEMBAHASAN}

Pelaksanaan sosialisasi dilakukan terdiri dari dua tahap kegiatan, yaitu:

a. Penyampaian materi tentang hand sanitizer dan potensi tanaman sirih sebagai bahan hand sanitizer

b. Simulasi pembuatan hand sanitizer daun sirih

Penyampaian materi diawali dengan memberikan pengetahuan umum kepada masyarakat tentang fungsi, bahan dasar yang umum digunakan, dan pengembangan teknologi terbaru dalam produksi hand sanitizer. Materi dilanjutkan dengan menjelaskan potensi bahan-bahan alam (natural product) sebagai bahan alternatif untuk pencegahan penularan virus atau bakteri, jenis-jenis natural product yang dapat dimanfaatkan, kandungan kimia yang umum terdapat pada natural product sebagai dasar pemanfaatannya sebagai anti virus maupun bakteri. Penjelasan materi ditutup dengan penjelasan tentang potensi dan tantangan penggunaan daun sirih sebagai hand sanitizer alternatif dimasa pandemic Covid-19.

Setelah itu kegiatan dilanjutkan dengan penyampaian prinsip penting dalam pembuatan hand sanitizer daun sirih yang disampaikan mencakup: a) Tahapan penyiapan, b) Tahap ekstraksi, dan c) Tahap penyimpanan. Tahap penyiapan secara umum terdiri dari pemilihan daun sirih, pencucian, pengeringan, dan perajangan. Pemilihan daun sirih berdasarkan kesegaran daun, hal ini dimaksudkan untuk mendapatkan jumlah senyawa bioaktif yang lebih banyak. Pencucian daun sirih menggunakan air bersih, sedangkan pengeringan dapat dilakukan pada suhu ruang maupun pengeringan menggunakan oven dengan kisaran suhu $60-80^{\circ} \mathrm{C}$. Suhu ini diasumsikan tidak merusak struktur senyawa bioaktif dari daun sirih. Penjarangan merupakan proses akhir dari tahap penyiapan. Penjarangan dimaksudkan untuk menjadikan permukaan daun sirin menjadi lebih luas, sehingga proses pengambilan senyawa 
bioaktif (proses ekstraksi) menjadi lebih optimal. Perajangan diupayakan mendapatkan daun sirih dengan ukuran sekecil mungkin.

Tahap ekstraksi menjadi tahap yang sangat ditekankan untuk dipahami oleh peserta. Ekstraksi merupakan tahap mendapatkan senyawa bioaktif daun sirih berdasarkan sifat kelarutan dan kepolaran. Dalam sosialisasi ini, tim pengabdi menjelaskan dua hal penting yaitu: a) peranan pelarut saat ekstraksi, dan b) pengaruh suhu ekstraksi. Pelarut yang digunakan dalam pembuatan hand sanitizer daun sirih yaitu air. Air memiliki peranan penting dalam proses ekstraksi, dimana air mempunyai sifat kepolaran yang baik sehingga efektif menarik senyawa bioaktif yang bersifat polar. Selain itu, ketersedian air yang melimpah, dan mudah ditemukan. Proses ekstraksi senyawa bioaktif daun sirih dilakukan dengan cara merendam daun sirih dalam air panas yang dilanjutkan dengan pengukusan selama 30 menit. Pengukusan menggunakan suhu rendah untuk mencegah kerusakan senyawa bioaktif.

Pembuatan hand sanitizer daun sirih diawali dengan menjelaskan bahan dan peralatan yang digunakan. Bahan yang digunakan yaitu daun sirih segar berukuran sedang, jeruk nipis, dan air. Sedangkan peralatan yang digunakan yaitu pisau, corong pemisah, wadah penampung berupa gelas kimia dan erlenmeyer, gelas ukur, dan alat pemanas. Wadah ini umumnya digunakan pada skala laboratorium, adapun skala rumah dapat menggunakan lain seperti panci dandan dan kompor.

Dalam kegiatan simulasi ini, pemisahan ekstrak daun sirih dilakukan menggunakan kertas saring. Hasil pemisahan ekstrak daun sirih berwarna kuning dengan sedikit aroma khas daun sirih. Pembentukan warna kuning disebabkan sifat senyawa bioaktif daun sirih yang mudah teroksidasi, sehingga untuk meminimalkan terbentuknya warna kuning dilakukan penambahan ekstrak jeruk nipis. Penambahan ekstrak jeruk nipis mempunyai dua fungsi yaitu a) mencegah senyawa bioaktif daun sirih teroksidasi, hal ini disebabkan adanya kandungan asam askorbat, dan b) menambah efektifitas anti virus atau mikroba dari ekstrak daun sirih, dimana ekstrak jeruk nipis juga dilaporkan mengandung senyawa bioaktif yang dapat menghambat pertumbuhan mikroorganisme.

Berikut terdapat beberapa foto yang berhasil didokumentasikan pada saat kegiatan berlangsung:

a. Penyampaian materi tentang hand sanitizer dan potensi tanaman sirih sebagai bahan hand sanitizer

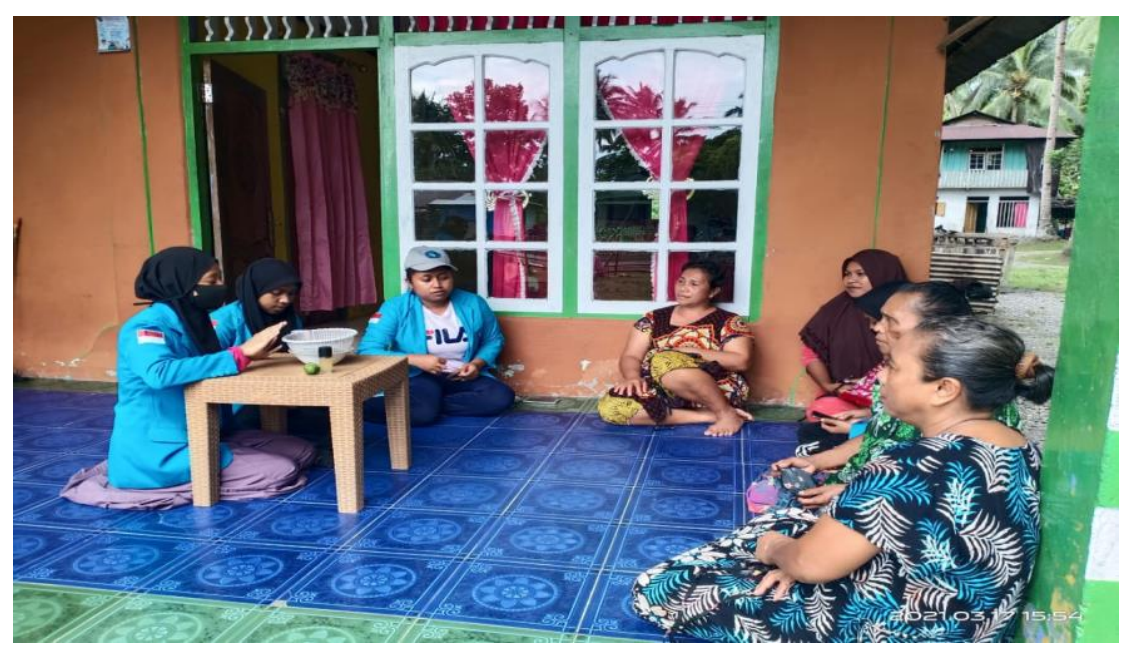

Gambar 1. Penyampaian materi tentang hand sanitizer dan potensi tanaman sirih sebagai bahan hand sanitizer 
b. Simulasi pembuatan hand sanitizer daun sirih

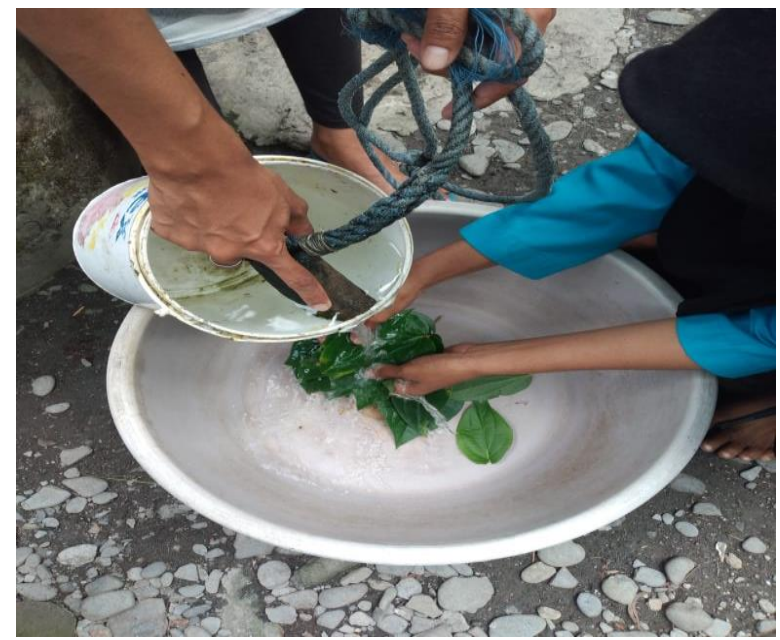

(a)

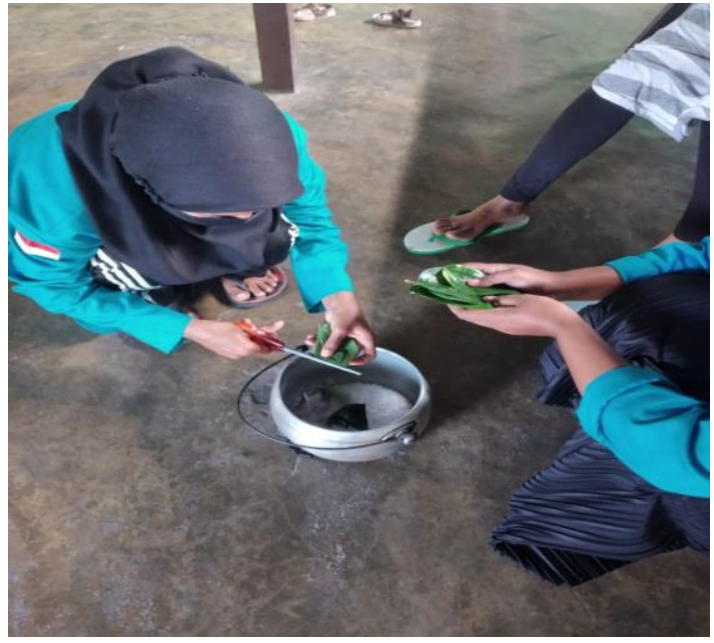

(b)

Gambar 2. (a) Proses pencucian daun sirih dan (b) Proses perajangan daun sirih

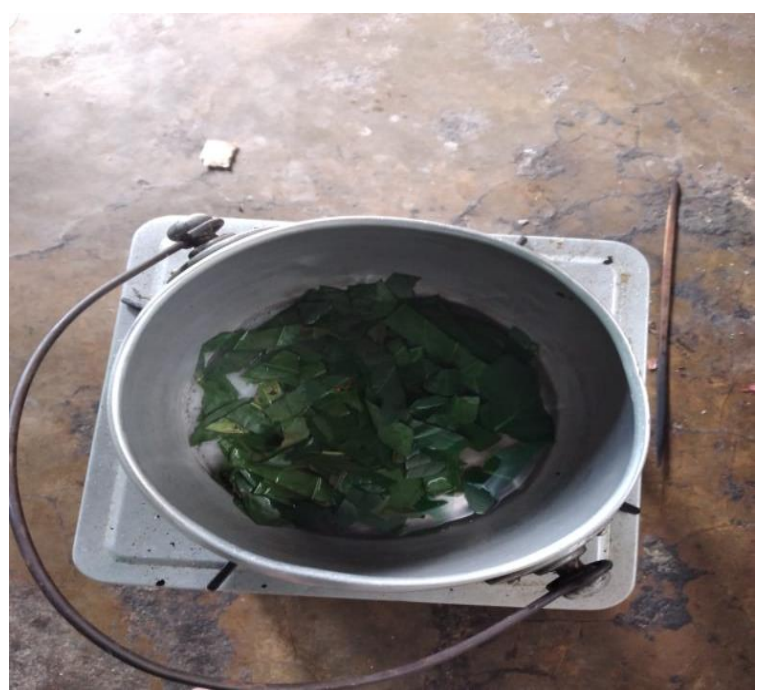

(a)

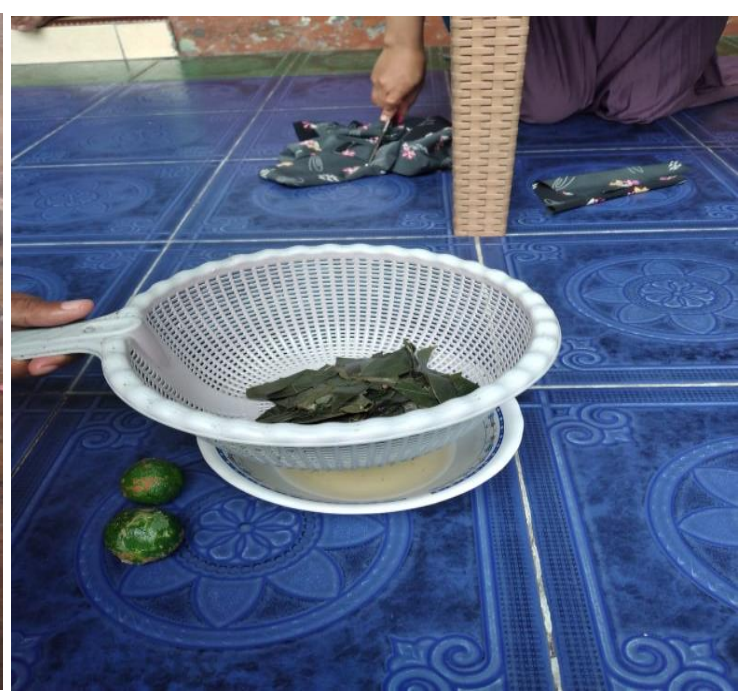

(b)

Gambar 3. (a) Proses memasak daun sirih dan (b) Proses penyulingan

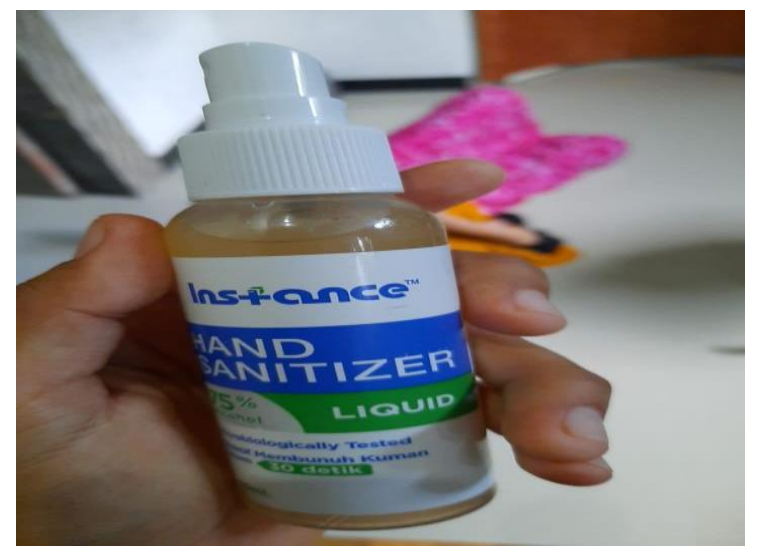

Gambar 4. Hasil produk hand sanitizer daun sirih 


\section{KESIMPULAN}

Kegiatan sosialisasi manfaat dan pembuatan hand sanitizer daun sirih pada Masyarakat Desa Tehoru Kabupaten Maluku Tengah telah sukses dilaksanakan. Metode pelaksaan kegiatan yang terdiri dari sosialisasi dan praktek pembuatan hand sanitizer efektif menambah: a) pengetahuan masyarakat tentang hand sanitizer dan potensi tanaman alam (natural product) seperti daun sirih sebagai bahan alternatif, dan b) ketrampilan (soft skill) masyarakat dalam pembuatan hand sanitizer alam. Hand sanitizer yang dibuat dalam kegiatan ini selanjutnya akan dimanfaatkan oleh masyarakat selama berada di luar rumah. Hand sanitizer daun sirih yang dibuat dalam kegiatan ini belum dapat dikomersialkan, akan tetapi telah dapat dimanfaatkan untuk kebutuhan perorangan dan keluarga. Hand sanitizer daun sirih masih memerlukan pengembangan lanjutan khususnya untuk pemanfaatan sebagai anti Covid- 19.

\section{DAFTAR PUSTAKA}

[1] Kemenkes RI, "Pedoman Pencegahan dan Pengendalian Coronavirus Disease (Covid-19)," Direktorat Jendral Pencegah. dan Pengenadalian Penyakit, pp. 0-115, 2020.

[2] V. F. E. Fitri Apriliany, Recta Oliva Umboro, "Penyuluhan Gema Cermat Obat dan Pelatihan Pembuatan Hand Sanitizer," J. Abdidas, vol. 2, no. 1, pp. 41-47, 2021.

[3] M. Tengku Putri Lindung Bulan, Yusnawati, "Sosialisasi Penggunaan dan Pembuatan Hand Sanitizer dalam Mengantisipasi Dampak Corona Virus Disease (Covid-19)," Glob. Sci. Soc. J. Ilm. Pengabdi. Kpd. Masy., vol. 3, no. 1, pp. 24-30, 2021.

[4] D. Fahruzi, "Pemberdayaan Masyarakat di Masa Pandei Melalui Pembuatan Hand Sanitizer dengan Antiseptik Alami," Univ. Negeri Semarang, 2020.

[5] N. A. A. Wakhid Muhlisin Hidayat, Muhamad Aziz, Luthfi Faishal Akbar, "Sosialisasi Pembuatan Hand Sanitizer Berbahan Dasar Lidah Buaya Sebagai Upaya Penerapan Pola Hidup Bersih Dan Sehat Di Masa Pandemi Covid-19," Univ. Negeri Semarang, 2020.

[6] D. N. Bima, S. P. Nadayu, and T. Y. Oktaviana, "Pembuatan Hand Sanitizer dari Limbah Kulit Jeruk," Univ. Diponegoro, pp. 334-338, 2020.

[7] L. Oktavia, T. Budiarti, D. Rahmawati, and E. Trisnowati, "Pemanfaatan Tumbuhan Sirih Hijau Sebagai Hand Sanitizer Alami Guna Pencegahan Covid-19 di Dusun Surojoyo," Abdipraja (Jurnal Pengabdi. Kpd. Masyarakat), vol. 2, no. 1, pp. 19-25, 2021.

[8] A. N. S. R. Netty Ermawati, Dwi Rahmawati, "Upaya Peningkatan Personal Higiene Masyarakat Melalui Pembuatan Hand Sanitizer Berbahan Alami," J. Kreat. Pengabdi. Kpd. Masy., vol. 4, no. 1, pp. 145-151, 2021.

[9] A. L. P. Ari Putra, Olen Okta Reza, "Pemberdayaan Keluarga Melalui Pembuatan Produk Home Industry Hand Sanitizer Alami di Masa Pandemi Covid-19," Diklus J. Pendidik. Luar Sekol., vol. 5, no. 1, pp. 14-24, 2021, doi: 10.21831/diklus.v5i1.38164.

[10] Niken, E. Arman, and H. D. Morika, "Lawan Covid-19:STIKes Syedza Saintika Salurkan Hand Sanitizer Sebagai Wujud Pengabdian Pada Masyarakat," J. Abdimas Saintika, vol. 2, no. 1, pp. 45-50, 2019.

[11] N. Nurhajijah, F. Fitria, and W. U. Harahap, "Pembuatan Hand Sanitizer Dan Alat Cuci Tangan Dengan Injak Di Desa Pematang Ganjang," PRODIKMAS J. Has. Pengabdi. Kpd. Masy., vol. 5, no. 1, pp. 11-14, 2020.

[12] R. Ginting, M. Huda, V. Drifanda, and A. R. Affandi, "Pemberdayaan Masyarakat Desa Jungsemi di Masa Pandemi Covid 19 Melalui Pelatihan Pembuatan Hand Sanitizer dan Pelindung Wajah," IJECS Indones. J. Empower. Community Serv., vol. 1, no. 1, pp. 20-27, 2020, doi: 10.32585/ijecs.v1i1.780.

[13] L. Adhani, Mayadi, S. Setiawati, and K. Fadhilla Ramdhania, "Sosialisasi Media Sosial dan Pembuatan Hand sanitizer, Hand soap Dalam Rangka Ikut serta Menanggulangi COVID19," J. Sains Teknol. dalam Pemberdaya. Masy., vol. 1, no. 1, pp. 11-18, 2020, doi: 10.31599/jstpm.v1i1.229. 